\title{
Determination of Leaf Dust Accumulation on Certain Plant Species Grown Alongside National Highway- 22, India
}

\author{
NAVJOT SINGH KALER ${ }^{\star}$, S.K. BHARDWAJ, K.S. PANT and T.S. RAI \\ Dr Y.S. Parmar University of Horticulture and Forestry, Nauni, Solan, H.P. 173230, India.
}

http://dx.doi.org/10.12944/CWE.11.1.10

(Received: March 14, 2016; Accepted: April 05, 2016)

\begin{abstract}
Vehicular traffic is one of the major contributors to accumulate dust on plants grown alongside roads. Plants intercept tons of dust, absorb noise and serve as acoustic screens on busy highways. Vegetation contributes in reducing dust concentration in environment by acting as a sink for air pollutants. Taking this into account, the present study was conducted on National highway- 22 from Parwanoo to Solan, falling in Solan district of Himachal Pradesh, India. Specifically, four plant species namely Grewia optiva Drummond ex Burret, Toona ciliata M. Roem, Melia azedarach L. and Woodfordia floribunda (L.) Kurz of uniform size, age, spread and common in occurrence on both sides of the highway were selected for the study. Dust accumulation on leaves of selected plants was estimated during three main seasons (Rainy, Winter and Summer) of the year. Samples were collected from two horizontal distances $(0-5 \mathrm{~m}$ and 5-10 $\mathrm{m})$ from both sides of the road. Results showed that dust accumulation on the leaves ranged from $0.0083 \mathrm{~g} \mathrm{~m}^{-2}$ in $T$. ciliata to $0.0597 \mathrm{~g} \mathrm{~m}^{-2}$ in G. optiva and followed the descending order G. optiva $>$ W. floribunda $>M$. azedarach $>T$. ciliata. Season wise, the examined plant species followed the descending order winter > summer > rainy season. Plants grown at a distance of 0-5 $\mathrm{m}$ accumulated higher dust on their leaves as compared to 5-10 m distance from the road. Due to surface characteristics of twigs, bark and foliage of the plants particulate matters are captured by them and remain there for extended time period. From the results of this study, it could be inferred that the air quality in urban/ arid areas can be improved by planting firstly the species $G$. optiva and $W$. floribunda along road sides of similar highways to national highway-22.
\end{abstract}

Keywords: National highway-22; Leaf dust; Seasonal variation;

Grewia optiva; Toona ciliata; Melia azedarach; Woodfordia floribunda; Solan.

\section{INTRODUCTION}

Air pollution is a major problem faced globally and mainly arising from industrialization, unplanned urbanisation, alarming increase in vehicle fleet and population growth. Thus, persons face great pressure $^{1}$ and their life quality is degraded ${ }^{2}$ from different points of view, e.g. climatic ${ }^{3}$.

With rapid development of human civilization and subsequent increased number of automobiles, air quality ultimately deteriorates. Road traffic is considered as one of the most important sources of both air and noise pollution. Motor vehicles account for $60-70 \%$ of the pollution found in an urban environment ${ }^{4}$. Besides, the airborne particulate matter commonly known as dust, also referred to Respirable Suspended Particulate Matter is also one of the major constituents of air pollution and itself comprises $40 \%$ of total air pollution problems in India 5 . Pollutants commonly found in dust on the roads can be potentially harmful to roadside vegetation, wildlife and the neighbouring human settlements ${ }^{6}$. Plants can be effectively used for monitoring air pollutants as different plant species respond to different types of air pollutants ${ }^{7}$ and provide enormous leaf area for the absorption and accumulation of air pollutants to reduce the pollution 
level in the air environment ${ }^{8}$. Generally exposed areas of a plant especially leaves act as constant absorbers for particulate matters ${ }^{9}$. Plant leaves have been regarded as bio-filters as they absorb large quantities of particles from the environment ${ }^{10}$. Thus air quality in urban/ arid areas can be improved by planting trees along road sides ${ }^{11,12}$ and agricultural lands ${ }^{13}$. However, dust accumulation capability of plants depends on their range of characteristics which include outside geometry, phyllotaxy and leaf attributes (cuticle and pubescence of leaves), tallness and canopy of plants. The accumulation of dust on plant leaves influence the leaf morphology, biochemical characteristics and exerts stress on plant physiology ${ }^{14,15,16}$. Sensitivity and response of plants to air pollutants is variable. The plant species which are more sensitive act as biological indicator of air pollution. The seasons of the years by impacting atmospheric deposition, interception of dust by leaves and the variation in weather parameters influence dust accumulation and biochemical concentrations in plant leaves. Plants have the potential to serve as an excellent quantitative and qualitative tool to evaluate the impact of air pollution ${ }^{17}$.

In Himachal Pradesh, the National Highway number 22 connecting the state capital Shimla and the major tourist hill spot is passing through Solan district. The large traffic load of this Highway is continuously polluting the ambient air of the region and ultimately influencing plant and human health. Consequently, determination of leaf dust accumulation from Parwanoo to Solan is generally employed for identifying tolerance level of plant species. The present study aims to investigate the leaf dust accumulation on certain plant species grown alongside road in order to compare their capability to accumulate particulates and trying to map the Particulate Matter pollution, to provide essential data for the recognition and control of air quality as well as for further environmental study.

\section{MATERIALS AND METHODS}

\section{Study area}

The entire study area extended from Parwanoo to Solan, geographically located in Solan district which lies between $30^{\circ} 44^{\prime} 53^{\prime \prime}$ and $31^{\circ} 22^{\prime} 01^{\prime \prime}$ $\mathrm{N}$ and between $76^{\circ} 36^{\prime} 10^{\prime \prime}$ and $77^{\circ} 15^{\prime} 14^{\prime \prime} \mathrm{E}$. The total distance of National Highway between Parwanoo and Solan is $41 \mathrm{~km}$ (Fig. 1). The National Highway on the way to Shimla, a famous tourist place is subjected to heavy traffic load. Besides, district being an education hub and gateway to horticulture produce outside the state highway is subjected to continuous heavy traffic load. The climate of the district is sub-tropical in the valley and tends to be temperate in the hilltops. Average annual rainfall in the district is about $1100 \mathrm{~mm}$ with average of 64 rainy days and Mean maximum and minimum temperature ranges between $34^{\circ} \mathrm{C}$ and $4^{\circ} \mathrm{C}$. The Parwanoo-Solan national highway falling in Solan district of Himachal Pradesh is on the hilly terrain having loose strata and generally moderately to steeply sloped with number of curves with altitude ranging from 350 to 1800 meter above mean sea level.

\section{Study method}

For conducting studies the whole area was divided in two parts, i) Parwanoo to Dharmpur ii) Dharmpur to Solan. The study was conducted during three seasons mainly winter (November, 2011), summer (May, 2012) and rainy (August, 2012). Four plant species viz.. Woodfordia floribunda, Toona ciliata, Melia azedarach and Grewia optiva were selected at two distances (D1: 0-5 m and D2: 5-10 m) from both sides of road for the present investigation. The plants selected for study were uniform with respect to their diameter at breast height $(1.37 \mathrm{~m})$, crown spread and were common in their occurrence on both sides of the highway. The relevant characteristic of these plants are shown in Table 1.

\section{Leaf dust accumulation}

Fully matured leaves of the selected plant species were taken randomly from different heights for the present study. The upper surfaces of the leaves were cleaned with fine brushes and identification marks were put on them. The leaves were kept for 24 hours for dust accumulation which was collected in the pre weighed butter paper bags with the help of fine brush. The amount of dust accumulated on leaves was weighed on top pan electronic balance (Model- CAC-34, Contech Instruments Limited, Bengaluru, India) and calculated by using the equation:

$$
\mathrm{W}=\mathrm{W} 2-\mathrm{W} 1 / \mathrm{A}
$$

Where; $W$ is dust content $\left(\mathrm{gm}^{-2}\right), \mathrm{W} 1$ is initial weight of butter paper bag, W2 is final weight 
of butter paper bag with dust, $A$ is total area of the leaf $\left(\mathrm{m}^{2}\right)$.

\section{Leaf area}

Ten leaves from each plant were collected at random and leaf area was measured with Leaf area meter (Model- $3100 \mathrm{C}$, LI-COR, Lincoln, USA). The average leaf area was expressed as $\mathrm{m}^{2}$.

\section{RESULTS AND DISCUSSION}

The perusal of data revealed that accumulation of dust on leaves varied in different species, in different seasons and at different distances (Table 2). Among plant species, highest dust accumulation was noticed in G. optiva $(0.0597$ $\left.\mathrm{g} \mathrm{m}^{-2}\right)$ followed by $W$. floribunda $\left(0.0371 \mathrm{~g} \mathrm{~m}^{-2}\right), M$. azedarach $\left(0.0167 \mathrm{~g} \mathrm{~m}^{-2}\right)$ whereas, lowest was

Table 1: Characteristics of selected plants at study site ${ }^{18}$

\begin{tabular}{|c|c|c|c|c|c|}
\hline $\begin{array}{l}\text { Name of } \\
\text { Plant }\end{array}$ & Family & $\begin{array}{l}\text { Common } \\
\text { name }\end{array}$ & Habit & $\begin{array}{l}\text { Leaf } \\
\text { shape }\end{array}$ & $\begin{array}{c}\text { Average } \\
\text { Plant } \\
\text { height } \\
\text { approx. (m) }\end{array}$ \\
\hline $\begin{array}{l}\text { Woodfordia } \\
\text { floribunda }\end{array}$ & Lythraceae & $\begin{array}{l}\text { Dhatki, } \\
\text { Dhawai }\end{array}$ & Shrub & Elliptical & 3 \\
\hline $\begin{array}{l}\text { Toona } \\
\text { ciliata }\end{array}$ & Meliaceae & $\begin{array}{c}\text { Toon, } \\
\text { Indian mahogany }\end{array}$ & Tree & $\begin{array}{c}\text { Elliptical } \\
\text { (Leaflet-Imparipinnate) }\end{array}$ & 25 \\
\hline $\begin{array}{l}\text { Melia } \\
\text { azedarach }\end{array}$ & Meliaceae & $\begin{array}{c}\text { Drek, } \\
\text { Bead tree }\end{array}$ & Tree & $\begin{array}{c}\text { Elliptical } \\
\text { (Leaflet-Tripinnate) }\end{array}$ & 18 \\
\hline $\begin{array}{l}\text { Grewia } \\
\text { optiva }\end{array}$ & Tiliaceae & $\begin{array}{l}\text { Dhaman, } \\
\text { Biul }\end{array}$ & Tree & Ovate & 12 \\
\hline
\end{tabular}

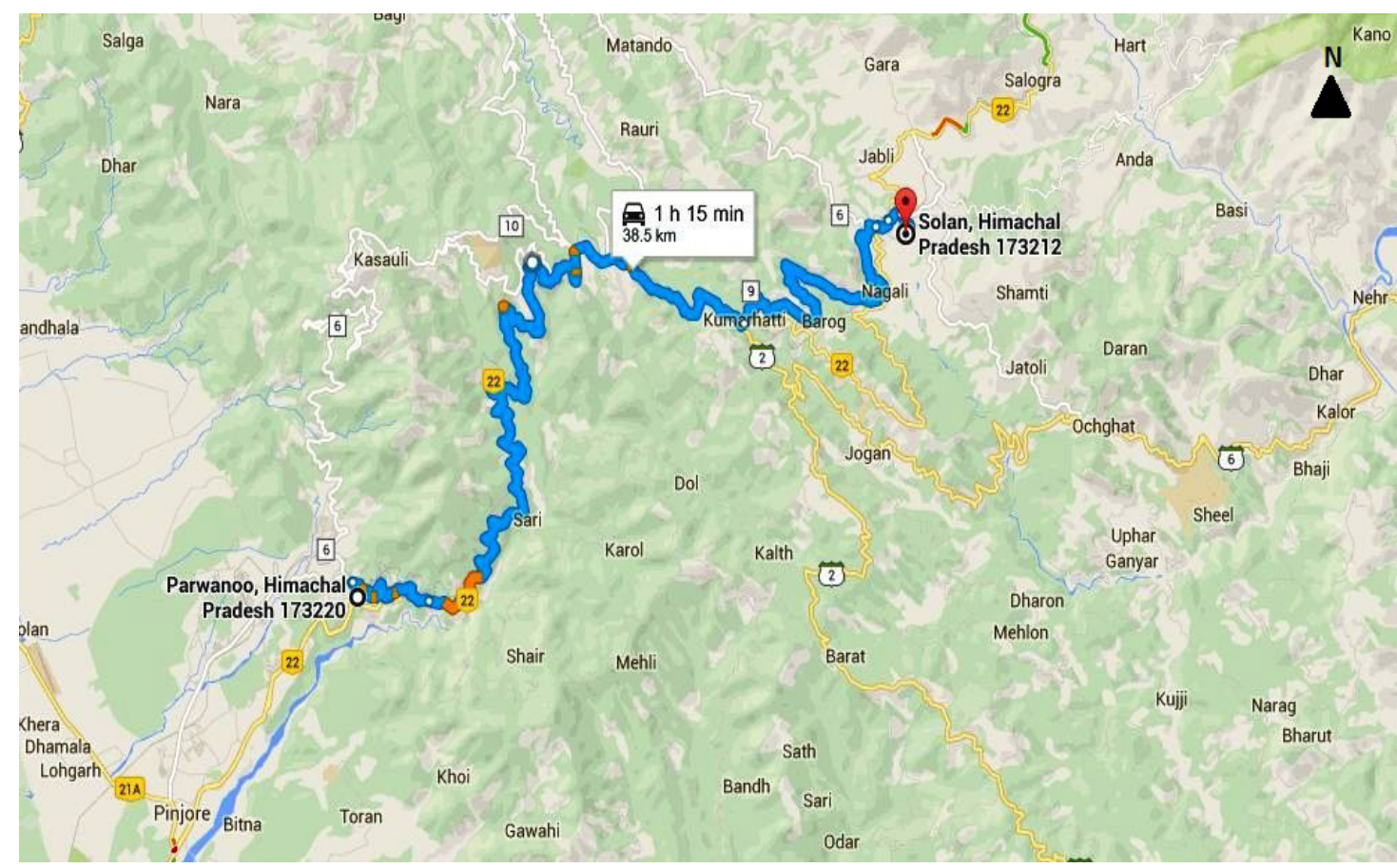

Fig. 1: Map showing the study area 


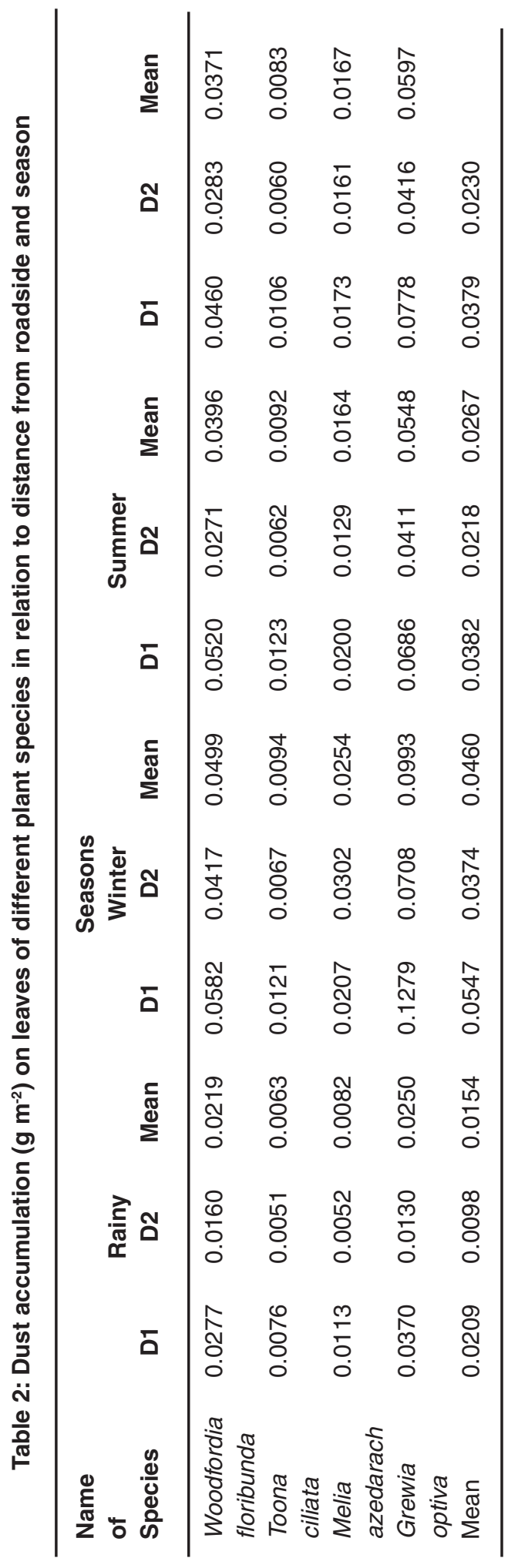

recorded in T. ciliata $\left(0.0083 \mathrm{~g} \mathrm{~m}^{-2}\right)$. The seasons of the year were found to influence the dust load on the leaves of the selected species. Irrespective of the species, highest dust deposition $\left(0.0460 \mathrm{~g} \mathrm{~m}^{-2}\right)$ was in winter followed by summer $\left(0.0267 \mathrm{~g} \mathrm{~m}^{-2}\right)$ and lowest noticed during rainy season $(0.0154 \mathrm{~g}$ $\mathrm{m}^{-2}$ ). Season wise, dust accumulation was in the order of winter $>$ summer $>$ rainy. The two distances selected for study were also found to have noticeable influence on leaf dust accumulation on different species under study. The highest dust accumulation $\left(0.0379 \mathrm{~g} \mathrm{~m}^{-2}\right)$, irrespective of plant species and seasons was recorded at 0-5 $\mathrm{m}$, whereas, lowest $\left(0.0230 \mathrm{~g} \mathrm{~m}^{-2}\right)$ was measured at $5-10 \mathrm{~m}$ from both side of road.

The present study shows that there is variation in pattern of dust accumulation on leaves of different plants, at different distances and in different seasons. Among plant species, highest dust accumulation, irrespective of seasons and distances was noticed in Grewia optiva, compared to other species and this may be ascribed to rough leaf surface, ovate shape and small petiole of this species. Whereas, lowest dust load on Toona ciliata may be due to surface smoothness and waxy coating on the leaves. Relatively, less dust accumulation on leaves of Woodfordia floribunda may be due to elliptical shape and sessile leaves and in leaves of Melia azedarach it may be due to tripinnate leaflets, waxy coating of leaf and long petiole. These findings are in conformity with the results of Vora and Bhatnagar and Garg et al. who have also reported dust accumulation as per the leaf characteristic of plants. The seasons of the year were found significantly influence the dust load on the leaves of the selected species. Irrespective of the species, highest dust deposition was in winter followed by in summer and lowest noticed in rainy season. This is in agreement with the findings of Prajapati and Tripathi who while studying seasonal variation of leaf dust accumulation and pigment content in plant species exposed to urban environment reported highest dust accumulation in winter followed by summer and rainy season. Prusty et al. also revealed seasonal variation of dust accumulation in vegetation near the national highway at Sambalpur in Orissa, India. The two distances selected for study were also found to have significant influence on leaf dust accumulation on different species under study. The highest dust 
accumulation irrespective of plant species and seasons was recorded at 0-5 meter, whereas, lowest was measured at 5-10 meters from roadsides. The present findings are in line with Walker and Everett who studied road dust and its environment impact on Alaskan taiga and tundra and reported that there is decrease in dust load on leaves with increasing distance from Highways. Spatt and Miller also reported that the dust arising from vehicular traffic settled in greatest quantities near the road with the amount rapidly decreasing away from the road.

The leaves of Grewia optiva accumulated the highest dust among selected plant species and followed the descending order Grewia optiva $>$ Woodfordia floribunda > Melia azedarach > Toona ciliata. Season wise, dust accumulation was in the descending order of winter > summer
$>$ rainy. The plants growing at a distance of 0-5 meter accumulated more dust on their leaves as compared to 5-10 $\mathrm{m}$ distance from the road. The present study reveals that evaluation of leaf dust accumulation on plants might be very useful in the selection of appropriate tree species for urban green belt development and their cultivation could be encouraged in large numbers to abate the problem of particulate pollution.

\section{ACKNOWLEDGEMENTS}

Authors are thankful to the Prof. G.S. Samet, Dean, College of Forestry, Department of Environmental Sciences, Dr. YS Parmar University of Horticulture and Forestry Nauni (Solan) for providing laboratory and library facility and their kind encouragement.

\section{REFERENCES}

1. Iatsoukis, A., Kamoutsis, A., Charalampopoulos, I., Panagiotou, I., and Chronopoulou-Sereli, A. Evaluation of biometeorological conditions of mountain communities and urban center in Greece. Proceedings of the International Conference on Environmental Management, Engineering, Planning and Economics Skiathos, June 2428: 1526-1530 (2007)

2. Matsoukis, A., Kamoutsis, A., Bollas, A., and Chronopoulou-Sereli, A. Biometeorological conditions in the urban park of Nea Smirni in the greater region of Athens, Greece during summer. Advances in Meteorology, Climatology and Atmospheric Physics, C.G. Helmis and P.T. Nastos (eds.), Springer Atmospheric Sciences, Springer-Verlag Berlin Heidelberg: 217-222 (2012)

3. Kamoutsis, A., Matsoukis, A., and Chronopoulos, K. Air temperature estimation by using artificial neural network models in the greater Athens area, Greece. ISRN Meteorology, 1-7 (2013)

4. Vijeta Verma and Neelam Chandra. Biochemical and Ultrastructural Changes in Sida cordifolia L. and Catharanthus roseus L. to Auto Pollution. International Scholarly Research Notices. 1-11 (2014)
5. Lone, P.M., Khan, A.A., and Shah S.A. Study of dust pollution caused by traffic in Aligarh city. Indian Journal of Environmental Health, 47(4): 33-36 (2005)

6. Bhattacharya, T., Chakraborty, S., Fadadu, B., and Bhattacharya, P. Heavy metal concentration in street and leaf deposited dust in Anand city, (India). Research Journal of Chemical Sciences, 1(5): 61-66 (2011)

7. Joshi, N.C. Experiments in Phytomonitoring of Urban Atmosphere, Ph.D. Thesis, University of Mumbai, Maharashtra, India. (1990)

8. Escobedo, F.J., Wagner, J.E., and Nowak, D.J. Analyzing the cost effectiveness of Santiago, Chile's policy of using urban forest to improve air quality. Journal of Environmental Management, 86: 148-157 (2008)

9. Samal, A.C., and Santra, S.C. Air quality of Kalyani township (Nadia, West Bengal) and its impact on surrounding vegetation. Indian Journal of Environmental Health, 44(1): 71-76 (2002)

10. Central Pollution Control Board (CPCB). Phytoremediation of particulate matter from ambient environment through dust capturing plant species, Report under Central Pollution Control Board, Ministry of Environment and Forests, Delhi. (2007) 
11. Beckett, K.P., Freer-Smith, P.H., and Taylor, G. Particulate pollution capture by urban trees: Effect of species and windspeed. Global Change Biology, 6: 995-1003 (2000)

12. Freer-Smith, P.H., Beckett, K.P., and Taylor, G. Deposition velocities to Sorbus aria, Acer campestre, Populus deltoides $\mathrm{x}$ trichocarpa 'Beaupre', Pinus nigra and $x$ Cupressocyparis leylandii for coarse, fine and ultrafine particles in the urban environment. Environmental Pollution, 133: 157-167 (2005)

13. Raupach, M.R., Woods, N., and Dorr, G. The entrapment of particles by windbreaks. Atmospheric Environment, 35: 3373-3383 (2001)

14. Somashekar, R.K., Ravikumar, R., and Ramesh, A.M. Impact of granite mining on some plant species around quarries and crusher of Bangalore district. Pollution Research, 18: 445-451 (1999)

15. Gostin, I.N. Air Pollution effects on the leaf structure of some Fabaceae species. Notulae Botanicae Horti Agrobotanici Cluj. 37: 57-63 (2009)

16. Sukumaran, D. Effect of Particulate Pollution on various Tissue Systems of Tropical Plants, Central Pollution Control Board (CPCB), Zonal Office, Kolkata, India. (2012)

17. Wagh, N.D., Shukla, P.V., Tambe, S.B., and Ingle S.T. Biological monitoring of roadside plants exposed to vehicular pollution in Jalgaon city. Journal of Environmental
Biology, 27(2): 419-421 (2006)

18. Luna, R.K. Plantation trees. International book distributer, Dehradun, India. (2005)

19. Vora, A.B., and Bhatnagar, A.R. Comparative study of dust fall on the leaves in high pollution and low pollution areas of Ahmedabad. Journal of Environmental Biology, 7(3): 155 163 (1986)

20. Garg, S.S., Kumar, N., and Das, G. Effects of the Bansal Ramraj Mill Dust on Vegetation and Health at Jaitwara, District Satna (M.P.). Indian Journal of Environmental Protection, 20(5): 326-328 (2000)

21. Prajapati, S.K., and Tripathi, B.D. Seasonal variation of leaf dust accumulation and pigment content in plant species exposed to urban particulates pollution. Journal of Environmental Quality, 37: 865-870 (2008)

22. Prusty, B.A., Mishra, P.C., and Azeez, P.A. Dust accumulation and leaf pigment content in vegetation near the national highway at Sambalpur Orissa, India. Ecotoxicological Environmental Safety. 60: 228-235 (2003)

23. Walker, D.A., and Everett, K.R. Road dust and its environmental impact on alaskan taiga and tundra. Arctic and Alpine Research, 19(4): 479-489 (1987)

24. Spatt, P.D., and Miller, C. Growth conditions and vitality of Sphagnum in a tundra community along the alaska pipeline haul road. Arctic, 34(1): 48-54 (1981) 